\title{
Preliminary Studies on Food and Water Consumption of Prediabetic Chinese Hamsters
}

\author{
Grorge C. Gerritsen and Margaret C. Blanks
}

Diabetes Research, The Upjohn Company, Kalamazoo, Michigan, USA

\begin{abstract}
Summary. The following measurements were made in prediabetic chinese hamsters: food and water consumption, urine volume and body weight. The prediabetics ate significantly more food than nondiabetic control hamsters. Although prediabetics ate $27 \%$ more than controls, body weights of the two groups were the same. An unexpected finding was that prediabetics drank significantly less water than their nondiabetic controls. - Although preliminary, the data suggest that prediabetic chinese hamsters have hyperphagia. It is possible that hyperphagia may contribute to the etiology of diabetes in this animal.
\end{abstract}

L'apport alimentaire et la consommation d'eau chez le hamster chinois prédiabétique: une étude préliminaire

Résumé. Les besoins en nourriture et en eau, le volume urinaire et le poids corporel ont été déterminés chez le hamster chinois prédiabétique. L'ingestion de nourriture est significativement plus élevée chez le hamster prédiabétique que chez le non-diabétique. Le poids corporel reste identique dans les deux groupes, bien que les prédiabétiques mangent $27 \%$ de plus que les animaux normaux. Un résultat inattendu est celui que les animaux prédiabétiques boivent significativement moins d'eau que leurs contrôles non-diabétiques. - Tout en restant préliminaires, ces données indiquent que les hamsters chinois ont une hyperphagie. II est possible que cette dernière puisse contribuer à l'étiologie du diabète chez cet animal.

Nahrungs- und Wasseraufnahme prädiabetischer chinesischer Hamster: Vorläufige Ergebnisse

Zusammenfassung. Die Kontroile der Nahrungs- und Wasseraufnahme, des Körpergewichts und des Urinvolumens prädiabetischer chinesischer Hamster ergab daß diese Tiere deutlich mehr Futter zu sich nehmen als Kontrolltiere. Obwohl die Nahrungsaufnahme der prädiabetischen Hamster um 27\% höher war als diejenige der Kontrollen, stieg ihr Körpergewicht im Vergleich zu demjenigen der Kontrolltiere nicht an. Unerwarteterweise tranken prädiabetische Tiere deutlich weniger als ihre Kontrollen. Obwohl diese Untersuchungen noch nicht beendet sind, scheint es auf Grund der vorliegenden Resultate daß prädiabetische chinesische Hamster hyperphagisch sind. Es ist deshalb möglich, daß die Hyperphagie in der Pathogenese des diabetischen Syndroms eine Rolle spielt.

Key-vords: Diabetes in animals, chinese hamster, cricetulus griseus, prediabetes, potential diabetes, food intake, hyperphagia in prediabetes.
There is considerable evidence which suggests a correlation between obesity due to hyperphagia and diabetes in both man [15] and animals [16,11, 13, 2, 9, $14,12,17,4]$. Further, there is some evidence that obesity and associated hyperphagia during the prediabetic state may contribute to the development of frank diabetes in both man [15] and animals [16]. Also, weight reduction through diet limitation has been shown to improve the metabolic state and normalize insulin levels in both man [10] and animals [6].

It has been observed that offspring from a mating of 2 ketotic chinese hamsters are prediabetic at birth since all subsequently develop the classical symptoms of diabetes $[8,7]$. Although chinese hamsters do not become obese, it was of interest to determine if prediabetics had hyperphagia.

\section{Methods}

Four prediabetic chinese hamsters, each with a different set of ketotic parents [8], were individually housed in stainless steel metabolism cages at the time they were weaned (24 days old). Each prediabetic was matched with a nondiabetic control of the same age, sex and weight. The nondiabetics were from sublines which had been free of diabetes for a minimum of 4 generations.

The animals were fed Purina Mouse Breeder chow.
Food was weighed into each cage and the food remaining after 7 days was reweighed. Each animal was weighed weekly. Four ounce calibrated baby bottles were used for drinking bottles and weekly water consumption was recorded. Twenty-four hour urine samples were collected, the volume measured and checked daily for sugar by Tes-Tape ${ }^{\circledR}$.

All 4 prediabetics developed diabetes as evidenced by heavy glucosuria $(4+$ Tes-Tape rating). Three of them developed glucosuria after 1 month of study while the fourth animal remained prediabetic until it was 6 -months old.

\section{Results}

Daily food consumption of the prediabetics was significantly greater than the nondiabetics (Table 1). Each 7-day food consumption period for each animal was calculated as granas/day. Three animals were studied for four 7-day periods before developing diabetes and the fourth hamster was studied for 16 weeks prior to onset of glucosuria. Each week of observations for each animal was considered as 1 observation. Therefore, 28 observations are listed in the table. Even though the prediabetics ate $27 \%$ more than the nondiabetics, body weights of the two groups did not differ.

Food consumption of the 1 prediabetic which did not develop glucosuria for 4 months of observation is 
plotted in Fig. 1. It is obvious that the animal consistently ate more than the nondiabetic control. There was no indication that the animal's food consumption changed radically as it approached frank diabetes. There was a slight decrease in food consumption of the prediabetic and its control as they approached maturity. This might be due to a decreasing growth rate.

Table 1. Food consumption and body weight of chinese hamsters

\begin{tabular}{llll}
\hline Type & $\begin{array}{l}\text { No. } \\
\text { animals }\end{array}$ & $\begin{array}{l}\text { No. } \\
\text { obser- } \\
\text { vations }\end{array}$ & $\begin{array}{l}\text { Food } \\
\text { g/day } \\
\text { S.E.a }\end{array}$ \\
\hline $\begin{array}{l}\text { Nondiabetic } \\
\text { Prediabetic }\end{array}$ & 4 & $\mathbf{2 8}$ & $\begin{array}{l}\text { Body wt. } \\
\text { g+S.E. }\end{array}$ \\
\hline
\end{tabular}

a Standard error

$\mathrm{P}<0.01$

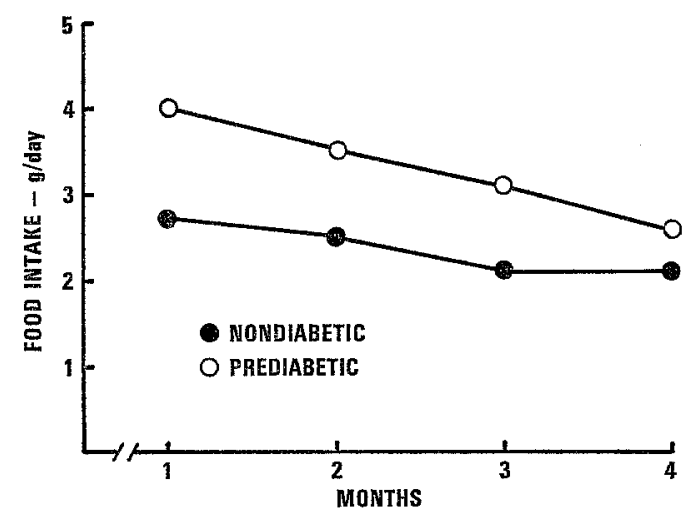

Fig. 1. Food consumption of chinese hamsters.

Table 2. Water consumption and urine excretion of chinese hamsters

\begin{tabular}{lllll}
\hline Type & $\begin{array}{l}\text { No. } \\
\text { animals }\end{array}$ & $\begin{array}{l}\text { No. } \\
\text { obser- } \\
\text { vations }\end{array}$ & $\begin{array}{l}\text { Water } \\
\text { ml/day } \\
\text { S.E. } .^{\mathrm{a}}\end{array}$ & $\begin{array}{l}\text { Urine } \\
\text { ml/day } \pm \\
\text { S.E. }{ }^{\mathrm{a}}\end{array}$ \\
\hline $\begin{array}{l}\text { Nondiabetic } \\
\text { Prediabetic }\end{array}$ & 4 & 28 & $\mathbf{5 . 4} \pm \mathbf{0 . 3}$ & $\mathbf{3 . 7} \pm 0.2$ \\
\hline
\end{tabular}

a Standard error of the mean

b $\mathrm{P}<0.02$

c $\mathrm{P}<0.001$

It was surprising that nondiabetics drank significantly more water and excreted a significantly greater volume of urine than the prediabetics (Table 2).

\section{Discussion}

Although the number of animals observed is small, the results are statistically significant. Without exception each prediabetic consistently consumed more food and drank less water than its control for each measurement interval.

If all 4 prediabetics had been siblings, one might suspect that something in their common genetic back- ground independent of diabetes was responsible for the observed hyperphagia. This explanation is not likely since all 4 prediabetics had different parents, although all 8 of the parents were severe ketotics.

The maternal environment during uterine life could have exerted an effect on appetite. As an example, the high maternal blood sugars might have stimulated hyperplasia of the fetal $\beta$-cells and/or increased insulin synthesis and secretion. Hyperinsulinism could explain increased food consumption by the prediabetics. If hyperinsulinism was responsible for hyperphagia in these prediabetics, obesity might be expected since obesity and hyperinsulinism appear to be associated $[15,16,10,6]$. Since obesity did not occur in these animals, hyperinsulinism may not be the cause of hyperphagia. Further, Carpenter et al. [3] have shown in another study that prediabetic chinese hamsters had normal blood sugar and plasma insulin levels and reduced granulation of the $\beta$-cells. However, hyperinsulinism as a cause of hyperphagia must remain an open question because blood sugar and plasma insulin levels were not measured in this study since trauma might alter food and water consumption.

Another possibility might be that the high blood sugar and ketone levels during uterine life adversely affect the appetite control mechanism. The observation that appetite of the prediabetic chinese hamster was abnormal is compatible with observations of others on diabetic animals. Coleman [5] has shown that $d b$ mice parabiosed to a nondiabetic eat while the nondiabetic dies of starvation. This suggests that diabetics do not respond to a satiety factor. Brodoff's results suggest that when the arcuate nucleus of the obese diabetic sand rat is lesioned, there is an ameliorative effect [1]. Strautz [18] has implanted islets from nonobese mice into their hyperphagic obese littermates. After implantation, weights were stabilized and hyperglycemia reduced.

Increased food consumption without an increase in weight is puzzling and difficult to explain. If the animals did not gain excess weight and did not have glucosuria, the question arises: where did the extra calories go? An explanation is not readily available. It is possible that absorption from the gut was low and the excess food was excreted via the feces. Unfortunately, this explanation must remain a hypothesis since fecal excretion was not measured.

It seems reasonable to expect that when food consumption is increased a concomitant rise in water consumption would occur. However, just the opposite was found in the prediabetios. There is no explanation for this surprising observation.

The limited data presented on prediabetic chinese hamsters have resulted in more questions than answers. However, the observation that food consumption is increased suggests that appetite might in some way contribute to the etiology of diabetes or that it might be secondary to other etiological factors. 


\section{References}

1. Brodoff, B.N., Zeballos G.: Further studies on the effect of hypothalamic lesions in the sand rat. Diabetologia 6, 366-370 (1970).

2. - Penhos, J.C., Levine, R.: The effects of feeding and various hormones on the glucose tolerance of the sand rat (Psammomys Obesus). Diabetologia 3, $167-170$ (1967).

3. Carpenter, A.-M., Gerritsen, G.C., Dulin, W.E., Lazarow, A.: Offspring of the matings of ketotic diabetic Chinese hamsters: Islet and beta cell volumes. Diabetologia.

4. Coleman, D.L., Hummel, K.P.: Studies with the mutation, diabetes, in the mouse. Diabetologia 3, $238-248$ (1967).

5. - - The effects of hypothalamic lesions in genetically diabetic mice. Diabetologia 6, 263-267 (1970).

6. Dulin, W.E., Wyse, B.M. : Diabetes in the KK mouse. Diabetologia 6, 317-323 (1970).

7. Gerritsen, G. C., Dulin, W. E.: Characterization of diabetes in the Chinese hamster. Diabetologia 3, 7484 (1967).

8. - Needham, L.B., Schmidt, F.L., Dulin, W.E.: Studies on the prediction and development of diabetes in offspring of diabetic Chinese hamsters. Diabetologia.

9. Gleason, R.E., Lauris, V., Soeldner, J. S. : Studies on experimental diabetes in the Wellesley hybrid mouse. III. Dietary effects and similar changes in a commercial Swiss-Hauschka strain. Diabetologia 3, 175-178 (1967).

10. Grodsky, G.M., Benoit, F.L.: Diabetes. Effect of massive weight reduction on insulin secretion in obese subjects, pp. 540-543. Ed. J. Östman. Amsterdam: Excerpta Medica Foundation 1969.
11. Hackel, D.B., Mikat, E., Lebovitz, H.E., SchmidtNielsen, K., Horton, E.S., Kinney, T.D.: The sand rat (Psammomys Obesus) as an experimental animal in studies of diabetes mellitus. Diabetologia 3, 130134 (1967).

12. Hellman, B.: Some metabolic aspects of the obesehyperglycemic syndrome in mice. Diabetologia $\mathbf{3}$, $222-229$ (1967).

13. Miki, E., Like, A.A., Steinke, J., Soeldner, J.S.: Diabetic syndrome in sand rats. II. Variability and association with diet. Diabetologia 3, 135-139 (1967).

14. Nakamura, M., Yamada, K.: Studies on a diabetic (KK) strain of mouse. Diabetologia 3, 212-221 (1967).

15. Östman, J.: Diabetes. X. Significance of the prediabetic state in the pathogenesis of obesity, pp. 525558. Amsterdam: Excerpta Medica Foundation 1969.

16. - Diabetes. XI. Spontaneous diabetes in animals, pp. 786-841. Amsterdam: Excerpta Medica Foundation 1969.

17. Stauffacher, W., Lambert, A.E., Vecchio, D., Renold, A.E.: Measurements of insulin activities in pancreas and serum of mice with spontaneous ("obese" and "New Zealand obese") and induced (goldthioglucose) obesity and hyperglycemia, with considerations on the pathogenesis of the spontaneous syndrome. Diabetologia 3, 230-237 (1967).

18. Strautz, R.L.: Studies of hereditary-obese mice (obob) after implantation of pancreatic islets in milipore filter capsules. Diabetologia 6, 306-312 (1970).

Dr. G.C. Gerritsen

Diabetes Research

The Upjohn Company

Kalamazoo, Michigan, USA 